\title{
Analisa Metode K-Means dalam Mengelompokkan Perkara Perceraian Berdasarkan Daerah Simalungun
}

\author{
Siti Humairoh Sa'dah', M. Safii², Iin Parlina ${ }^{3}$ \\ STIKOM Tunas Bangsa Pematangsiantar, \\ Jl.Jendral Sudirman Blok A No.1, 2, 3 Pematangsiantar \\ Sitihumairohsadah350@gmail.com
}

\begin{abstract}
Abstrak - Perceraian merupakan realita terpahit yang dilami oleh suatu individu, sesungguhnya benar adanya bahwa perceraian yang dilakukan akan menyelesaikan masalah yang terjadi dalam rumah tangga. Namun, tidak menutup kemungkinan akan hadir masalah baru dari dampak perceraian tersebut. Tercatat bahwa per tahunnya angka perceraian meningkat sampai dengan 10 \% dengan berasumsikan perkara dengan kriteria yang pada umumnya terjadi. Dari kasus tersebut peneliti melakukan pengembangan menggunakan metode $k$-means clustering untuk mendapatkan daerah yang banyak melakuakan tindakan perceraian, dari hasil tersebut diharapkan hasil penelitian agar dapat memberi solusi yang tepat yakni mampu memmetakkan daerah - daerah yang melakukan perceraian. Hasil clustering menunjukkan bahwa tingkat perceraian yang tertinggi di daerah Simalungun, untuk cluster pertama sebanyak 5 daerah, untuk cluster kedua sebanyak 8 daerah dan cluster ketiga sebanyak 22 daerah.
\end{abstract}

Kata Kunci : K-Means, Clustering, Data Mining, Perceraian

Abstract - Divorce is the bitterest reality experienced by an individual, it is true that divorce will solve problems that occur in the household. However, it is possible that a new problem will arise from the impact of the divorce. It is noted that the divorce rate increases annually by $10 \%$ by assuming cases with criteria that generally occur. From these cases the researchers developed using the k-means clustering method to get an area that did a lot of divorce actions, from these results it is hoped that the results of the research can provide the right solution that is able to put the regions in divorce. The clustering results show that the divorce rate is highest in the Simalungun area, for the first cluster of 5 regions, for the second cluster as many as 8 regions and the third cluster as many as 22 regions.

Keywords: K-Means, Clustering, Data Mining, Divorce

\section{PENDAHULUAN}

Perceraian adalah cerai hidup antara pasangan suami-istri akibat dari kegagalan mereka yang tidak sesuai dalam menjalankan fungsinya masing masing dan juga adanya faktor eksternal yang sangat mendukung. Perceraian merupakan terputusnya keluarga karena salah satu atau kedua pasangan memutuskan untuk saling meninggalkan sehingga mereka berhenti menjalankan fungsinya sebagai suami-istri. Perceraian pada hakekatnya adalah suatu proses dimana hubungan suami isteri tatkala tidak ditemui lagi keharmonisan dalam pernikahan. Sumatera Utara pada umumnya dan khususnya di Pengadilan Agama Simalungun merupakan salah satu pengadilan yang menangani peningkatan perceraian pertahunnya. Permasalahan dari perceraian tersebut adalah tugas 
besar bagi negara dan kurangnya kontrol sosial masyarakat sekitar. Kondisi tersebut menunjukkan bahwa Indonesia saat ini menghadapi penurunan dibidang sosial diakrenakan kurangnya perhatian Negara. Berdasarkan permasalahan tersebut, penulis berinisiatif untuk melakukan penelitian dalam mengelompokkan daerah mana yang melakukan perceraian dengan menggunakan metode Data Mining Clustering.

\section{METODOLOGI PENELITIAN}

\subsection{Data Mining}

Data mining adalah proses mencari pola atau informasi menarik dalam data terpilih dengan menggunakan teknik atau metode tertentu. Teknik, metode, atau algoritma dalam data mining sangat bervariasi. Data Mining terdiri dari beberapa fase yaitu estimasi, klustering, prediksi, klasifikasi dan asosiasi. Data Mining klasifikasi memiliki salah satu metode yaitu K-Means. K-Means merupakan salah satu tekhnik pengelompokkan hierarchial clustering dilakukan secara bertahap dan disetiap iterasi dari pengelompokkan hierarchial clustering hanya ada satu pemilihan penggabungan suatu item terhadap item lainnya [1].

\subsection{Algoritma K-Means}

K-Means merupakan algoritma klasterisasi yang mengelompokkan data berdasarkan titik pusat klaster (centroid) terdekat dengan data. Tujuan dari $K$ Means adalah pengelompokkan data dengan memaksimalkan kemiripan data dalam satu klaster dan meminimalkan kemiripan data antarklaster. Ukuran kemiripan yang digunakan dalam klaster adalah fungsi jarak. Sehingga pemaksimalan kemiripan data didapatkan berdasarkan jarak terpendek antara data terhadap titik centroid [2]-[8]. Tahapan awal yang dilakukan pada proses klasterisasi data dengan menggunakan algoritma K-Means adalah pembentukan titik awal centroid cj. Pada umumnya pembentukan titik awal centroid dibangkitkan secara acak [9].

\subsection{Pernikahan}

Pernikahan merupakan suatu ikatan yang suci yang dilakukan anatara perempuan dengan laki-laki begitu juga sebaliknya, berharap agar pernikahan yang dijalankan sekali dalam seumur hidup serta mendapatakan ketenangan dan kenyamanan antara kedua belah pihak dalam berumah tangga kelak. Pengesahan suatu hukum cara pernikahan biasanya terjadi pada saat dokumen tertulis yang mencatatkan pernikahan serta ditandatangani, pengesahan dokumen tertulis tersebut merupakan aturan dari pemerintah

\subsection{Perceraian}

Perceraian merupakan berakhirnya suatu pernikahan. Saat kedua pasangan tersebut tidak ingin lagi melanjutkan kehidupan pernikahannya, pada dasarnya hal ini disebabkan oleh banyak faktor salah satunya anatara suami dan istri sudah tidak menjalankan fungsinya dengan baik. Perceraian ada 2 jenisnya : cerai hidup dan cerai mati. Cerai hidup juga terbagi menjadi 2 bagian cerai talaq dan cerai gugat, cerai talaq yakni cerai yang diajukan oleh pihak suami terhadap istri 
sedangkan cerai gugat adalah cerai yang diajukan oleg istri terhadap suami dengan melakukan permohonan kepada pengadilan agama setempat. Dikesempatan ini saya akan melakukan riset dalam perkara cerai hidup (cerai talaq dan cerai gugat).

\subsection{Pengertian Rapidminer}

Rapidminer merupakan perangkat lunak yang dibuat oleh Dr. Markus Hofmann dari Institute of Technologi Blanchardstown dan Ralf Klinkenberg dari rapid-i.com dengan tampilan GUI (Graphical User Interface) sehingga memudahkan pengguna dalam menggunakan perangkat lunak ini. Perangkat lunak ini bersifat open source dan dibuat dengan menggunakan program Java di bawah lisensi GNU Public Licence dan Rapid Miner dapat dijalankan di sistem operasi manapun. Dengan menggunakan Rapid Miner, tidak dibutuhkan kemampuan koding khusus, karena semua fasilits sudah disediakan. Rapid Miner dikhususkan untuk penggunaan data mining. Model yang disediakan juga cukup banyak dan lengkap, seperti Model Bayesian, Modelling, Tree Induction, Neural Network dan lain-lain [10].

\section{HASIL DAN PEMBAHASAN}

\subsection{Perhitungan Algoritma K-Means}

Dalam melakukan Clustering, data yang diperoleh akan dihitung terlebih dahulu berdasarkan jumlah Kecamatan di kabupaten Simalungun. Hasil penjumlahan berdasarkan 3 kriteria penilaian yakni KDRT (Kekerasan dalam Rumah Tangga), Ekonomi dan Sosial.

Tabel 1. Data Perkara Perceraian Tahun 2017 di Kabupaten Simalungun

\begin{tabular}{|c|c|c|c|c|c|c|c|}
\hline \multicolumn{8}{|c|}{ ANALISA ALGORITMA PERCERAIAN KABUPATEN SIMALUNGUN 2017} \\
\hline \multirow{3}{*}{ NO } & \multicolumn{2}{|c|}{ Alamat } & \multirow{2}{*}{\multicolumn{2}{|c|}{ Jenis Perkara }} & \multirow{2}{*}{\multicolumn{3}{|c|}{ Juni }} \\
\hline & \multirow{2}{*}{ Kecamatan } & \multirow{2}{*}{ Nagori } & & & & & \\
\hline & & & $\mathrm{T}$ & G & C1 & $\mathrm{C} 2$ & C3 \\
\hline 1 & Tanah Jawa & Marbun Jaya & $\mathrm{v}$ & & & & $\mathrm{V}$ \\
\hline 2 & Pematang Bandar & Kerasaan 1 & $\mathrm{~V}$ & & & & $\mathrm{~V}$ \\
\hline 3 & Tanah Jawa & Baja Dolok & & $\mathrm{V}$ & & $\mathrm{V}$ & \\
\hline 4 & Ujung Padang & Riah Naposo & & $\mathrm{V}$ & & & $\mathrm{V}$ \\
\hline 5 & Ujung Padang & Riah Naposo & & $\mathrm{V}$ & & $\mathrm{V}$ & \\
\hline 6 & Dolok Batu Nanggar & Bandar Selamat & & $\mathrm{V}$ & & & $\mathrm{V}$ \\
\hline 7 & Siantar & Marihat Baris & & $\mathrm{V}$ & & & $\mathrm{V}$ \\
\hline 8 & Bosar Maligas & Sei Mangke & & $\mathrm{V}$ & & & $\mathrm{V}$ \\
\hline 9 & Siantar Martoba & Tambun Nabolon & $\mathrm{v}$ & & & & $\mathrm{V}$ \\
\hline 10 & Jawa Maraja Bah Jambi & Bah Joga & & V & & & $\mathrm{V}$ \\
\hline 11 & Pematang Bandar & Kerasaan 1 & & $\mathrm{~V}$ & & $\mathrm{~V}$ & \\
\hline 12 & Bosar Maligas & Rejo Tani & $\mathrm{V}$ & & & & $\mathrm{V}$ \\
\hline 13 & Bandar Huluan & Tanjung Hataran & & $\mathrm{V}$ & & $\mathrm{V}$ & \\
\hline 14 & Dolok Batu Nanggar & Bahung Kahean & $\mathrm{v}$ & & & & $\mathrm{V}$ \\
\hline 15 & Tanah Jawa & Baja Dolok & & $\mathrm{V}$ & & $\mathrm{V}$ & \\
\hline 16 & Bosar Maligas & Tempel Jaya & $\mathrm{v}$ & & & & $\mathrm{V}$ \\
\hline 17 & Pematang Sidamanik & Sait Buttu Saribu & & $\mathrm{V}$ & & & $\mathrm{V}$ \\
\hline 18 & Tanah Jawa & Totap Majawa & $\mathrm{V}$ & & & & $\mathrm{V}$ \\
\hline 19 & Siantar Barat & Bantan & $\mathrm{V}$ & & & & $\mathrm{V}$ \\
\hline
\end{tabular}




\begin{tabular}{|c|c|c|c|c|c|c|c|c|c|c|c|c|c|c|}
\hline \multicolumn{15}{|c|}{ Jumlah Kasus Perceraian di Tahun 2017 Pengadilan Agama Simalungun } \\
\hline No & Kecamatan & Januari & Februari & Maret & April & Mei & Juni & Juli & Agustus & September & Oktober & November & Desember & Jumlah \\
\hline 1 & Dolok Kahean & 0 & 0 & 0 & 0 & 1 & 0 & 0 & 0 & 0 & 0 & 0 & 0 & 1 \\
\hline 2 & Dolok Panribuan & 1 & 0 & 0 & 0 & 0 & 0 & 0 & 0 & 0 & 0 & 0 & 0 & 1 \\
\hline 3 & $\begin{array}{l}\text { Dolok Batu } \\
\text { Nanggar }\end{array}$ & 10 & 3 & 4 & 3 & 7 & 2 & 10 & 6 & 6 & 7 & 8 & 6 & 72 \\
\hline 4 & Ujung Padang & 5 & 0 & 4 & 6 & 2 & 2 & 8 & 2 & 3 & 2 & 6 & 3 & 43 \\
\hline 5 & Bandar & 11 & 5 & 5 & 6 & 6 & 0 & 8 & 11 & 5 & 7 & 9 & 7 & 80 \\
\hline 6 & Bandar Masilam & 4 & 0 & 1 & 5 & 7 & 0 & 1 & 4 & 2 & 4 & 3 & 3 & 34 \\
\hline 7 & Bandar Jawa & 1 & 0 & 0 & 0 & 0 & 0 & 0 & 0 & 0 & 0 & 0 & 0 & 1 \\
\hline 9 & Pematang Bandar & 4 & 3 & 5 & 3 & 5 & 2 & 6 & 6 & 2 & 6 & 5 & 1 & 48 \\
\hline 10 & $\begin{array}{l}\text { Pematang } \\
\text { Sidamanik }\end{array}$ & 4 & 0 & 0 & 1 & 0 & 1 & 0 & 1 & 2 & 1 & 0 & 0 & 10 \\
\hline 11 & Sidamanik & 1 & 1 & 1 & 1 & 1 & & 3 & 1 & 1 & 3 & 1 & 1 & 15 \\
\hline 12 & Siantar & 7 & 4 & 5 & 10 & 3 & 1 & 7 & 9 & 9 & 13 & 9 & 3 & 80 \\
\hline 13 & Siantar Barat & 0 & 0 & 0 & 0 & 0 & 1 & 0 & 0 & 0 & 0 & 0 & 0 & 1 \\
\hline 14 & Siantar Timur & 0 & 0 & 0 & 0 & 0 & 0 & 0 & 0 & 0 & 0 & 0 & 1 & 1 \\
\hline 15 & Siantar Selatan & 0 & 0 & 0 & 0 & 0 & 0 & 0 & 0 & 1 & 0 & 0 & 0 & 1 \\
\hline 16 & Siantar Utara & 1 & 0 & 0 & 0 & 0 & 0 & 0 & 0 & 0 & 0 & 0 & 0 & 1 \\
\hline 17 & Siantar Martoba & 0 & 0 & 0 & 0 & 0 & 1 & 0 & 0 & 0 & 1 & 1 & 2 & 5 \\
\hline 19 & Gunung Malela & 16 & 6 & 3 & 4 & 6 & & 8 & 9 & 10 & 6 & 8 & 0 & 76 \\
\hline 20 & $\begin{array}{l}\text { Jawa Maraja Bah- } \\
\text { Jambi }\end{array}$ & 3 & 3 & 4 & 2 & 3 & 1 & 1 & 2 & 1 & 3 & 5 & 0 & 28 \\
\hline 21 & Kerasaan & 0 & 0 & 0 & 0 & 1 & 0 & 0 & 0 & 0 & 0 & 0 & 0 & 1 \\
\hline 22 & Tapian Dolok & 16 & 11 & 5 & 4 & 9 & & 6 & 9 & 6 & 5 & 6 & 5 & 82 \\
\hline 23 & Tanah Jawa & 5 & 2 & 2 & 1 & 6 & 4 & 0 & 2 & 9 & 8 & 3 & 2 & 44 \\
\hline 24 & Hatonduhan & 1 & 0 & 2 & 0 & 1 & 0 & 0 & 2 & 1 & 0 & 1 & 0 & 8 \\
\hline 25 & Ujung Bandar & 0 & 0 & 0 & 0 & 0 & 0 & 0 & 0 & 0 & 1 & 0 & 0 & 1 \\
\hline 26 & Jorlang Hataran & 1 & 1 & 1 & 0 & 1 & & 3 & 0 & 1 & 1 & 3 & 1 & 13 \\
\hline 27 & $\begin{array}{l}\text { Girsang Sipangan } \\
\text { Bolon }\end{array}$ & 1 & 2 & 0 & 0 & 1 & 0 & 0 & 0 & 1 & 1 & 0 & 0 & 6 \\
\hline 28 & Setia Janji & 0 & 0 & 0 & 0 & 0 & 0 & 0 & 0 & 0 & 0 & 0 & 0 & 0 \\
\hline 29 & Dolok Panribuan & 1 & 0 & 0 & 0 & 0 & 0 & 0 & 0 & 0 & 0 & 0 & 0 & 1 \\
\hline 30 & Bosar Maligas & 10 & 4 & 4 & 1 & 3 & 3 & 8 & 3 & 3 & 1 & 2 & 1 & 43 \\
\hline 31 & Gunung Maligas & 3 & 2 & 2 & 5 & 1 & & 4 & 3 & 2 & 6 & 4 & 4 & 36 \\
\hline
\end{tabular}

\subsection{Centroid Data}

Penentuan titik cluster ini dilakukan dengan mengambil nilai terbesar (maksimum) untuk cluster daerah kecamatan perkara perceraian paling tinggi (C1), nilai rata-rata (average) untuk cluster daerah kecamatan perkara perceraian sedang (C2) dan nilai terkecil (minimum) untuk cluster daerah kecamatan perkara perceraian paling sedikit (C3). Nilai titik tersebut dapat diketahui pada Tabel 3.3 berikut:

Tabel 2. Centroid Data Awal

\begin{tabular}{|c|c|c|}
\hline cluster tinggi & cluster sedang & cluster rendah \\
\hline 55,53333333 & 25,07407407 & 2,428571428 \\
\hline
\end{tabular}

\subsection{Clustering Data}

Proses cluster dengan mengambil jarak terdekat dari setiap data yang diolah. Dari data perkara Perceraian tahun 2015 dan 2016, dan 2017 di Kabupaten Simalungun. Didapatkan pengelompokan pada iterasi 1 untuk 3 cluster tersebut. Cluster daerah yang paling banyak melakukan perceraian (C1) yakni 5 kecamatan, cluster daerah yang sedang melakukan perceraian (C2) yakni 9 kecamatan, dan cluster kecamatan yang paling sedikit melakukan perceraian (C3) yakni 21 kecamatan. Proses pencarian jarak terpendek, pengelompokan data pada iterasi 1 dan Clustering data dapat digambarkan pada tabel dan gambar berikut: 
Tabel 3. Perhitungan Jarak Pusat Cluster

\begin{tabular}{|c|c|c|c|c|c|c|c|}
\hline NO & Kecamatan & Rata -Rata & C1 & $\mathrm{C} 2$ & C3 & Jarak Terpendek & HASIL 1 \\
\hline 1 & Gunung Malela & 48,66666667 & 14 & 32,82857143 & 48,33333334 & 14 & 1 \\
\hline 2 & Tapian Dolok & 53 & 9,66666667 & 37,16190476 & 52,66666667 & 9,66666667 & 1 \\
\hline 3 & Bandar Huluan & 21,33333333 & 41,33333334 & 5,495238092 & 21 & 5,495238092 & 3 \\
\hline 4 & Ujung Padang & 33,66666667 & 29 & 17,82857143 & 33,33333334 & 17,82857143 & 2 \\
\hline 5 & Sidamanik & 12,33333333 & 50,33333334 & 3,504761908 & 12 & 3,504761908 & 2 \\
\hline 6 & Tanah Jawa & 33 & 29,66666667 & 17,16190476 & 32,66666667 & 17,16190476 & 2 \\
\hline 7 & Bandar & 62,666666667 & 0 & 46,82857143 & 62,33333334 & 0 & 1 \\
\hline 8 & Dolok Batu Nanggar & 55,33333333 & 7,33333334 & 39,49523809 & 55 & 7,33333334 & 1 \\
\hline 9 & Bosar Maligas & 35 & 27,66666667 & 19,16190476 & 34,66666667 & 19,16190476 & 2 \\
\hline 10 & Bandar Masilam & 24 & 38,66666667 & 8,161904762 & 23,66666667 & 8,161904762 & 2 \\
\hline 11 & Pematang Bandar & 26,666666667 & 36 & 10,82857143 & 26,33333334 & 10,82857143 & 2 \\
\hline 12 & Bandar Pulo & 0,333333333 & 62,33333334 & 15,50476191 & 0 & 0 & 3 \\
\hline 13 & Jawa Maraja Bahjambi & 18 & 44,66666667 & 2,161904762 & 17,66666667 & 2,161904762 & 2 \\
\hline 14 & Gunung Maligas & 31 & 31,66666667 & 15,16190476 & 30,66666667 & 15,16190476 & 2 \\
\hline 15 & Panei Tongah & 0,666666667 & 62 & 15,17142857 & 0,333333334 & 0,333333334 & 3 \\
\hline 16 & Huta Bayu Raja & 12 & 50,66666667 & 3,838095238 & 11,66666667 & 3,838095238 & 2 \\
\hline 17 & Pematang Sidamanik & 6,6666666667 & 56 & 9,171428571 & 6,333333334 & 6,333333334 & 3 \\
\hline 18 & Dolok Panribuan & 0,666666667 & 62 & 15,17142857 & 0,333333334 & 0,333333334 & 3 \\
\hline 19 & Bandar Pasir Mandoge & 0,333333333 & 62,33333334 & 15,50476191 & 0 & 0 & 3 \\
\hline 20 & Hatonduhan & 3,666666667 & 59 & 12,17142857 & 3,333333334 & 3,333333334 & 3 \\
\hline 21 & Jorlang Hataran & 7 & 55,66666667 & 8,838095238 & 6,666666667 & 6,666666667 & 3 \\
\hline 22 & Girsang Sipangan Bolon & 3,666666667 & 59 & 12,17142857 & 3,333333334 & 3,333333334 & 3 \\
\hline 23 & Siantar & 58 & 4,66666667 & 42,16190476 & 57,66666667 & 4,66666667 & 1 \\
\hline 24 & Siantar Utara & 0,333333333 & 62,33333334 & 15,50476191 & 0 & 0 & 3 \\
\hline 25 & Siantar Timur & 0,333333333 & 62,33333334 & 15,50476191 & 0 & 0 & 3 \\
\hline 26 & Siantar Barat & 1,333333333 & 61,33333334 & 14,50476191 & 1 & 1 & 3 \\
\hline 27 & Siantar Martoba & 2 & 60,66666667 & 13,83809524 & 1,666666667 & 1,666666667 & 3 \\
\hline 28 & Kerasaan & 0,333333333 & 62,33333334 & 15,50476191 & 0 & 0 & 3 \\
\hline 29 & Batu Nanggar & 0,333333333 & 62,33333334 & 15,50476191 & 0 & 0 & 3 \\
\hline 30 & Air Putih & 0,333333333 & 62,33333334 & 15,50476191 & 0 & 0 & 3 \\
\hline 31 & Bandar Jawa & 0,333333333 & 62,33333334 & 15,50476191 & 0 & 0 & 3 \\
\hline 32 & Dolok Kahean & 0,333333333 & 62,33333334 & 15,50476191 & 0 & 0 & 3 \\
\hline 33 & Dolok Merawan & 0,333333333 & 62,33333334 & 15,50476191 & 0 & 0 & 3 \\
\hline 34 & Setia Janji & 0,333333333 & 62,33333334 & 15,50476191 & 0 & 0 & 3 \\
\hline 35 & Ujung Bandar & 0,333333333 & 62,33333334 & 15,50476191 & 0 & 0 & 3 \\
\hline
\end{tabular}

Tabel 4. Pengelompokkan Data Iterasi 1

\begin{tabular}{|c|l|c|c|c|}
\hline \multirow{2}{*}{ No } & \multicolumn{2}{|c|}{ Kecamatan } & \multicolumn{3}{|c|}{ Kelompok Data } \\
\cline { 3 - 5 } & & C1 & C2 & C3 \\
\hline 1 & Gunung Malela & 1 & & \\
\hline 2 & Tapian Dolok & 1 & & \\
\hline 3 & Bandar Huluan & & 1 & \\
\hline 4 & Ujung Padang & & 1 & \\
\hline 5 & Sidamanik & & & 1 \\
\hline 6 & Tanah Jawa & 1 & & \\
\hline 7 & Bandar & 1 & & \\
\hline 8 & Dolok Batu Nanggar & & 1 & \\
\hline 9 & Bosar Maligas & & 1 & \\
\hline 10 & Bandar Masilam & & 1 & \\
\hline 11 & Pematang Bandar & & & 1 \\
\hline 12 & Bandar Pulo & & 1 & \\
\hline 13 & Jawa Maraja Bahjambi & & 1 & \\
\hline 14 & Gunung Maligas & & & 1 \\
\hline 15 & Panei Tongah & & & 1 \\
\hline 16 & Huta Bayu Raja & & & 1 \\
\hline 17 & Pematang Sidamanik & & \\
\hline
\end{tabular}




\begin{tabular}{|c|l|c|c|c|}
\hline \multirow{2}{*}{ No } & \multicolumn{2}{|c|}{ Kecamatan } & \multicolumn{3}{c|}{ Kelompok Data } \\
\cline { 3 - 5 } & & C1 & C2 & C3 \\
\hline 18 & Dolok Panribuan & & & 1 \\
\hline 19 & Bandar Pasir Mandoge & & & 1 \\
\hline 20 & Hatonduhan & & & 1 \\
\hline 21 & Jorlang Hataran & & & 1 \\
\hline 22 & Girsang Sipangan Bolon & & & 1 \\
\hline 23 & Siantar & 1 & & \\
\hline 24 & Siantar Utara & & & 1 \\
\hline 25 & Siantar Timur & & & 1 \\
\hline 26 & Siantar Barat & & & 1 \\
\hline 27 & Siantar Martoba & & & 1 \\
\hline 28 & Kerasaan & & & 1 \\
\hline 29 & Batu Nanggar & & & 1 \\
\hline 30 & Air Putih & & & 1 \\
\hline 31 & Bandar Jawa & & & 1 \\
\hline 32 & Dolok Kahean & & & 1 \\
\hline 33 & Dolok Merawan & & & 1 \\
\hline 34 & Setia Janji & & 1 \\
\hline 35 & Ujung Bandar & & \\
\hline
\end{tabular}

$\mathrm{C} 1:\{1,2,7,8,23\}$

$\mathrm{C} 2:\{4,5,6,9,10,11,13,14,16\}$

C3 : $\{3,12,15,17,18,19,20,21,22,24,25,26,27,28,29,30,31,32,33,34,35\}$

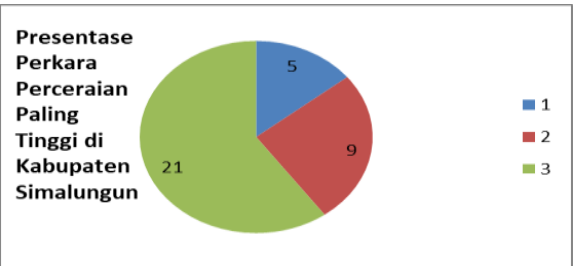

Gambar 1. Clustering Data

Proses K-Means akan terus beriterasi sampai pengelompokan data sama dengan pengelompokan data iterasi sebelumnya. Proses iterasi tersebut berhenti pada iterasi ke 3, pada iterasi 3 akan dilakukan proses mencari nilai titik tengah atau centroid yang dapat diketahui pada Tabel 6 berikut :

Tabel 5. Data Centroid Iterasi 3

\begin{tabular}{|c|c|c|}
\hline cluster tinggi & cluster sedang & cluster rendah \\
\hline 55,53333333 & 27,83333333 & 2,454545454 \\
\hline
\end{tabular}

Setelah mendapatkan nilai titik tengah atau centroid, proses sama dilakukan dengan mencari jarak terdekat. Proses pencarian jarak terpendek, pengelompokan data pada iterasi 3 dan Clustering data dapat digambarkan pada tabel dan gambar berikut:

Tabel 6. Perhitungan Jarak Pusat Cluster Iterasi 3

\begin{tabular}{|c|c|c|c|c|c|c|c|}
\hline NO & Kecamatan & Rata -Rata & c1 & c2 & c3 & $\begin{array}{c}\text { Jarak } \\
\text { Terpendek }\end{array}$ & hasil 3 \\
\hline 1 & Gunung Malela & $\begin{array}{l}48,666666 \\
7\end{array}$ & $\begin{array}{l}6,8666666 \\
6\end{array}$ & $\begin{array}{l}20,8333333 \\
4\end{array}$ & $\begin{array}{l}46,2121212 \\
2\end{array}$ & 6,866666666 & \\
\hline
\end{tabular}

Mengelompokkan Perkara Perceraian (Siti Humairoh Sa'dah) | 354 


\begin{tabular}{|c|c|c|c|c|c|c|c|}
\hline NO & Kecamatan & Rata -Rata & c1 & c2 & c3 & $\begin{array}{c}\text { Jarak } \\
\text { Terpendek }\end{array}$ & hasil 3 \\
\hline 2 & Tapian Dolok & 53 & $\begin{array}{l}2,5333333 \\
3\end{array}$ & $\begin{array}{l}25,1666666 \\
7\end{array}$ & $\begin{array}{l}50,5454545 \\
5\end{array}$ & 2,53333333 & 1 \\
\hline 3 & Bandar Huluan & $\begin{array}{l}21,333333 \\
3\end{array}$ & 34,2 & 6,5 & $\begin{array}{l}18,8787878 \\
8\end{array}$ & 6,5 & 2 \\
\hline 4 & Ujung Padang & $\begin{array}{l}33,666666 \\
7\end{array}$ & $\begin{array}{l}21,866666 \\
7\end{array}$ & 5,83333334 & $\begin{array}{l}31,2121212 \\
2\end{array}$ & 5,83333334 & 2 \\
\hline 5 & Sidamanik & $\begin{array}{l}12,333333 \\
3\end{array}$ & 43,2 & 15,5 & $\begin{array}{l}9,87878787 \\
6\end{array}$ & 9,878787876 & 3 \\
\hline 6 & Tanah Jawa & 33 & $\begin{array}{l}22,533333 \\
3\end{array}$ & 5,16666667 & $\begin{array}{l}30,5454545 \\
5\end{array}$ & 5,16666667 & 2 \\
\hline 7 & Bandar & $\begin{array}{l}62,666666 \\
7\end{array}$ & $\begin{array}{l}7,1333333 \\
4\end{array}$ & $\begin{array}{l}34,8333333 \\
4\end{array}$ & $\begin{array}{l}60,2121212 \\
2\end{array}$ & 7,13333334 & 1 \\
\hline 8 & Dolok Batu Nanggar & $\begin{array}{l}55,333333 \\
3\end{array}$ & 0,2 & 27,5 & $\begin{array}{l}52,8787878 \\
8\end{array}$ & 0,2 & 1 \\
\hline 9 & Bosar Maligas & 35 & $\begin{array}{l}20,533333 \\
3\end{array}$ & 7,16666667 & $\begin{array}{l}32,5454545 \\
5\end{array}$ & 7,16666667 & 2 \\
\hline 10 & Bandar Masilam & 24 & $\begin{array}{l}31,533333 \\
3\end{array}$ & 3,83333333 & $\begin{array}{l}21,5454545 \\
5\end{array}$ & 3,83333333 & 2 \\
\hline 11 & Pematang Bandar & $\begin{array}{l}26,666666 \\
7\end{array}$ & $\begin{array}{l}28,866666 \\
7\end{array}$ & 1,16666666 & $\begin{array}{l}24,2121212 \\
2\end{array}$ & 1,16666666 & 2 \\
\hline 12 & Bandar Pulo & $\begin{array}{l}0,3333333 \\
3\end{array}$ & 55,2 & 27,5 & $\begin{array}{l}2,12121212 \\
1\end{array}$ & 2,121212121 & 3 \\
\hline 13 & Jawa Maraja Bahjambi & 18 & $\begin{array}{l}37,533333 \\
3\end{array}$ & 9,83333333 & $\begin{array}{l}15,5454545 \\
5\end{array}$ & 9,83333333 & 2 \\
\hline 14 & Gunung Maligas & 31 & $\begin{array}{l}24,533333 \\
3\end{array}$ & 3,16666667 & $\begin{array}{l}28,5454545 \\
5\end{array}$ & 3,16666667 & 2 \\
\hline 15 & Panei Tongah & $\begin{array}{l}0,6666666 \\
7\end{array}$ & $\begin{array}{l}54,866666 \\
7\end{array}$ & $\begin{array}{l}27,1666666 \\
6\end{array}$ & $\begin{array}{l}1,78787878 \\
7\end{array}$ & 1,787878787 & 3 \\
\hline 16 & Huta Bayu Raja & 12 & $\begin{array}{l}43,533333 \\
3\end{array}$ & $\begin{array}{l}15,8333333 \\
3\end{array}$ & $\begin{array}{l}9,54545454 \\
6\end{array}$ & 9,545454546 & 3 \\
\hline 17 & Pematang Sidamanik & $\begin{array}{l}6,6666666 \\
7\end{array}$ & $\begin{array}{l}48,866666 \\
7\end{array}$ & $\begin{array}{l}21,1666666 \\
6\end{array}$ & $\begin{array}{l}4,21212121 \\
3\end{array}$ & 4,212121213 & 3 \\
\hline 18 & Dolok Panribuan & $\begin{array}{l}0,6666666 \\
7\end{array}$ & $\begin{array}{l}54,866666 \\
7\end{array}$ & $\begin{array}{l}27,1666666 \\
6\end{array}$ & $\begin{array}{l}1,78787878 \\
7\end{array}$ & 1,787878787 & 3 \\
\hline 19 & Bandar Pasir Mandoge & $\begin{array}{l}0,3333333 \\
3\end{array}$ & 55,2 & 27,5 & $\begin{array}{l}2,12121212 \\
1\end{array}$ & 2,121212121 & 3 \\
\hline 20 & Hatonduhan & $\begin{array}{l}3,6666666 \\
7\end{array}$ & $\begin{array}{l}51,866666 \\
7\end{array}$ & $\begin{array}{l}24,1666666 \\
6\end{array}$ & $\begin{array}{l}1,21212121 \\
3\end{array}$ & 1,212121213 & 3 \\
\hline 21 & Jorlang Hataran & 7 & $\begin{array}{l}48,533333 \\
3\end{array}$ & $\begin{array}{l}20,8333333 \\
3\end{array}$ & $\begin{array}{l}4,54545454 \\
6\end{array}$ & 4,545454546 & 3 \\
\hline 22 & $\begin{array}{l}\text { Girsang Sipangan } \\
\text { Bolon }\end{array}$ & $\begin{array}{l}3,6666666 \\
7\end{array}$ & $\begin{array}{l}51,866666 \\
7\end{array}$ & $\begin{array}{l}24,1666666 \\
6\end{array}$ & $\begin{array}{l}1,21212121 \\
3\end{array}$ & 1,212121213 & 3 \\
\hline 23 & Siantar & 58 & $\begin{array}{l}2,4666666 \\
7\end{array}$ & $\begin{array}{l}30,1666666 \\
7\end{array}$ & $\begin{array}{l}55,5454545 \\
5 \\
\end{array}$ & 2,46666667 & 1 \\
\hline 24 & Siantar Utara & $\begin{array}{l}0,3333333 \\
3\end{array}$ & 55,2 & 27,5 & $\begin{array}{l}2,12121212 \\
1\end{array}$ & 2,121212121 & 3 \\
\hline 25 & Siantar Timur & $\begin{array}{l}0,3333333 \\
3\end{array}$ & 55,2 & 27,5 & $\begin{array}{l}2,12121212 \\
1\end{array}$ & 2,121212121 & 3 \\
\hline 26 & Siantar Barat & $\begin{array}{l}1,3333333 \\
3\end{array}$ & 54,2 & 26,5 & $\begin{array}{l}1,12121212 \\
1\end{array}$ & 1,121212121 & 3 \\
\hline 27 & Siantar Martoba & 2 & $\begin{array}{l}53,533333 \\
3\end{array}$ & $\begin{array}{l}25,8333333 \\
3\end{array}$ & $\begin{array}{l}0,45454545 \\
4\end{array}$ & 0,454545454 & 3 \\
\hline 28 & Kerasaan & $\begin{array}{l}0,3333333 \\
3\end{array}$ & 55,2 & 27,5 & $\begin{array}{l}2,12121212 \\
1\end{array}$ & 2,121212121 & 3 \\
\hline 29 & Batu Nanggar & $\begin{array}{l}0,3333333 \\
3\end{array}$ & 55,2 & 27,5 & $\begin{array}{l}2,12121212 \\
1\end{array}$ & 2,121212121 & 3 \\
\hline 30 & Air Putih & $\begin{array}{l}0,3333333 \\
3\end{array}$ & 55,2 & 27,5 & $\begin{array}{l}2,12121212 \\
1\end{array}$ & 2,121212121 & 3 \\
\hline 31 & Bandar Jawa & $\begin{array}{l}0,3333333 \\
3\end{array}$ & 55,2 & 27,5 & $\begin{array}{l}2,12121212 \\
1\end{array}$ & 2,121212121 & 3 \\
\hline 32 & Dolok Kahean & $\begin{array}{l}0,3333333 \\
3\end{array}$ & 55,2 & 27,5 & $\begin{array}{l}2,12121212 \\
1\end{array}$ & 2,121212121 & 3 \\
\hline 33 & Dolok Merawan & 0,3333333 & 55,2 & 27,5 & 2,12121212 & 2,121212121 & 3 \\
\hline
\end{tabular}




\begin{tabular}{|l|l|l|l|l|l|l|l|}
\hline NO & \multicolumn{1}{|c|}{ Kecamatan } & Rata -Rata & \multicolumn{1}{c|}{ c1 } & \multicolumn{1}{c|}{ c2 } & \multicolumn{1}{c|}{ c3 } & $\begin{array}{c}\text { Jarak } \\
\text { Terpendek }\end{array}$ & hasil 3 \\
\hline & & 3 & & & 1 & & \\
\hline 34 & Setia Janji & 0,33333333 & 55,2 & 27,5 & 2,121212121 & 2,121212121 & 3 \\
\hline 35 & Ujung Bandar & 0,33333333 & 55,2 & 27,5 & 2,121212121 & 2,121212121 & 3 \\
\hline
\end{tabular}

Tabel 7. Pengelompokkan Data Iterasi 3

\begin{tabular}{|c|l|c|c|c|}
\hline \multirow{2}{*}{ No } & \multicolumn{1}{|c|}{ Kecamatan } & \multicolumn{3}{c|}{ Kelompok Data } \\
\hline & & C1 & C2 & C3 \\
\hline 1 & Gunung Malela & 1 & & \\
\hline 2 & Tapian Dolok & & 1 & \\
\hline 3 & Bandar Huluan & & 1 & \\
\hline 4 & Ujung Padang & & & 1 \\
\hline 5 & Sidamanik & & 1 & \\
\hline 6 & Tanah Jawa & 1 & & \\
\hline 7 & Bandar & 1 & & \\
\hline 8 & Dolok Batu Nanggar & & 1 & \\
\hline 9 & Bosar Maligas & & 1 & \\
\hline 10 & Bandar Masilam & & 1 & \\
\hline 11 & Pematang Bandar & & & 1 \\
\hline 12 & Bandar Pulo & & 1 & \\
\hline 13 & Jawa Maraja Bahjambi & & 1 & \\
\hline 14 & Gunung Maligas & & & 1 \\
\hline 15 & Panei Tongah & & & 1 \\
\hline 16 & Huta Bayu Raja & & & 1 \\
\hline 17 & Pematang Sidamanik & & & 1 \\
\hline 18 & Dolok Panribuan & & & 1 \\
\hline 19 & Bandar Pasir Mandoge & & & 1 \\
\hline 20 & Hatonduhan & & & 1 \\
\hline 21 & Jorlang Hataran & & & 1 \\
\hline 22 & Girsang Sipangan Bolon & & & 1 \\
\hline 23 & Siantar & 1 & & \\
\hline 24 & Siantar Utara & & & 1 \\
\hline 25 & Siantar Timur & & & 1 \\
\hline 26 & Siantar Barat & & & 1 \\
\hline 27 & Siantar Martoba & & \\
\hline 28 & Kerasaan & & & 1 \\
\hline 29 & Batu Nanggar & & & \\
\hline 30 & Air Putih & & & \\
\hline 31 & Bandar Jawa & & & \\
\hline 32 & Dolok Kahean & & & \\
\hline 33 & Dolok Merawan & & & \\
\hline 34 & Setia Janji & Ujung Bandar & & \\
\hline
\end{tabular}

C1 : $\{1,2,7,8,23\}$

C2 : $\{3,4,6,9,10,11,13,14\}$

C3 : $\{5,12,15,16,17,18,19,20,21,22,24,25,26,27,28,29,30,31,32,33,34,35\}$ 


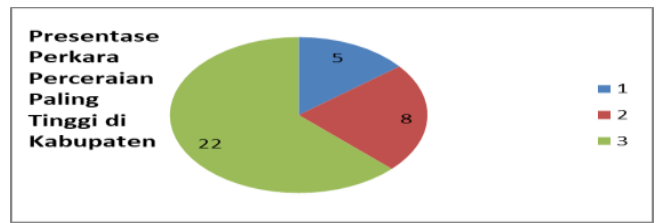

Gambar 2. Clustering Data

Pada iterasi 3, pengelompokan data yang dilakukan terhadap 3 cluster dengan iterasi 2 didapatkan hasil yang sama. Dari 35 data berdasarkan jumlah kecamatan yang ada di Kabupaten Simalungun dapat dikertahui, 5 kecamatan cluster paling tinggi (C1) yakni (Gunung Malela, Tapian Dolok, Bandar, Dolok Batu Nanggar, Siantar), 8 kecamatan cluster sedang (C2) yakni (Bandar Huluan, Ujung Padang, Tanah Jawa, Bosar Maligas, Bandar Masilam, Pematang Bandar, Jawa Maraja Bah-Jammbi, Gunung Maligas), dan 22 kecamatan cluster rendah (C3) yakni (Sidamanik, Bandar Pulo, Panei Tongah, Huta Bayu Raja, Pematang Sidamanik, Dolok Panribuan, Bandar Pasir Mandoge, Hatonduhan, Jorlang Hataran, Girsang Sipangan Bolon, Siantar Utara, Siantar Timur, Siantar Barat, Siantar Martoba, Kerasaan, Batu Nanggar, Air Putih. Bandar Jawa, Dolok Kahean, Dolok Merawan, Setia Janji, Ujung Bandar).

\section{KESIMPULAN}

Berdasarkan pembahasan sebelumnya dapat disimpulkan bahwa:

a. Penerapan Datamining dengan menggunakan algoritma K-Means dalam pengelompokan perkara perceraian pada cluster 1 sebanyak 5, cluster 2 sebanyak 8 dan cluster 3 sebanyak 22 .

b. Pengujian data pada Rapidminer 5.3 menggunakan K-Means dapat menampilkan tiga kelas dari hasil klasifikasi.

\section{DAFTAR PUSTAKA}

[1] F. Kiki and A. P. Windarto, "DATA MINING : PENERAPAN RAPIDMINER DENGAN K-MEANS CLUSTER PADA DAERAH TERJANGKIT DEMAM BERDARAH DENGUE ( DBD ) BERDASARKAN PROVINSI," vol. 3, no. 2, pp. 173-178, 2018.

[2] I. Parlina, A. P. Windarto, A. Wanto, and M. R. Lubis, "Memanfaatkan Algoritma K-Means dalam Menentukan Pegawai yang Layak Mengikuti Asessment Center untuk Clustering Program SDP," CESS (Journal of Computer Engineering System and Science), vol. 3, no. 1, pp. 87-93, 2018.

[3] M. G. Sadewo, A. P. Windarto, and D. Hartama, "Penerapan Datamining Pada Populasi Daging Ayam Ras Pedaging Di Indonesia Berdasarkan Provinsi Menggunakan K-Means," InfoTekJar (Jurnal Nasional Informatika dan Teknologi Jaringan), vol. 2, no. 1, pp. 60-67, 2017.

[4] M. G. Sadewo, A. P. Windarto, and A. Wanto, "Penerapan Algoritma Clustering dalam Mengelompokkan Banyaknya Desa/Kelurahan Menurut Upaya Antisipasi/ Mitigasi Bencana Alam Menurut Provinsi dengan K-Means," KOMIK (Konferensi Nasional Teknologi Informasi dan Komputer), vol. 2, no. 1, pp. 311-319, 2018.

[5] R. W. Sari, A. Wanto, and A. P. Windarto, "Implementasi Rapidminer dengan Metode K-Means (Study Kasus: Imunisasi Campak pada Balita Berdasarkan Provinsi)," KOMIK (Konferensi Nasional Teknologi Informasi dan Komputer), vol. 2, no. 1, pp. 224-230, 2018.

[6] S. Sudirman, A. P. Windarto, and A. Wanto, "Data Mining Tools | RapidMiner : K-Means 
Method on Clustering of Rice Crops by Province as Efforts to Stabilize Food Crops In Indonesia," IOP Conference Series: Materials Science and Engineering, vol. 420, no. 12089, pp. 1-8, 2018.

[7] A. P. Windarto, "Implementation of Data Mining on Rice Imports by Major Country of Origin Using Algorithm Using K-Means Clustering Method," International Journal of artificial intelligence research, vol. 1, no. 2, pp. 26-33, 2017.

[8] A. P. Windarto, "Penerapan Data Mining Pada Ekspor Buah-Buahan Menurut Negara Tujuan Menggunakan K-Means Clustering,” Techno.COM, vol. 16, no. 4, pp. 348-357, 2017.

[9] Adrian Asroni Ronal, "Penerapan Metode K-Means Untuk Clustering Mahasiswa Berdasarkan Nilai Akademik Dengan Weka Interface Studi Kasus Pada Jurusan Teknik Informatika UMM Magelang," vol. 18, no. 1, pp. 76-82, 2015.

[10] S. Haryati, A. Sudarsono, and E. Suryana, "Implementasi Data Mining untuk Memprediksi Masa Studi Mahasiswa Menggunakan Algoritma C4.5," Jurnal Media Infotama, vol. 11, no. 2, pp. 130-138, 2015. 